of $£ 3,000$ from the Treasury has again been reduced by 10 per cent, and it has only been possible to spend $£ 2,337$ on books, the smallest expenditure for seven years. The financial difficulties are the more unfortunate when the work of the Library in tracing out-of-the-way books and acting as a clearing-house for the entire library system of Great Britain and a chief source of all bibliographical information is becoming more widely known and appreciated. The report contains references to the 'outlier libraries'which now number 149, including those of a number of research associations, the regional library systems, the university libraries, and the foreign librarieswhich will probably surprise the average scientific worker in the extent to which they reveal the coordination of effort in this field. Moreover, as the regional system grows, the work represented by each book issued by the Central Library continues to increase, as although the number of books issued may decrease the percentage of books difficult to trace and obtain becomes higher. Of particular interest is work on Union Catalogues, and the Union List of Periodicals in the University Libraries has been of the greatest service in locating periodicals. The report also refers to a Union List of Scientific, Technical and Commercial Periodicals in the Public, the University and all the Technical Libraries in Sheffield. A total of 61,187 books was issued by the National Central Libraries and 11,231 by the outlier libraries, which contain 5,846,000 volumes; 2,409 books were lent to university libraries, 1,233 of which were supplied from the Library's own stock.

\section{Thermo-couple Standardisation}

THE use of thermocouples for the measurement of temperature has become so customary in industry that the issue by the Bureau of Standards of the United States of a pamphlet of 36 pages by Messrs. W. F. Roeser and H. T. Wensel on the methods of testing them and the materials of which they are constructed will be welcomed by many workers in industry. It is Research Paper 768 of the Bureau, and is issued at the low price of 5 cents. It deals with the best materials to use for a given range of temperature, how to secure that they are pure and how to standardise the couples when constructed. On the whole, the authors prefer a freezing point rather than a boiling point for a standard temperature when each is available, but instructions are given for carrying out standardisations in each way and also for comparisons with working standards of the thermo-couple type. The best methods of interpolating for temperatures between the standard temperatures are also dealt with. Some idea of the accuracy to be expected from observations with various types of thermo-couples over different ranges of temperature is also given.

\section{The World Power Conference}

Ar the annual meeting of the International Executive Council of the World Power Conference, held at the Royal Netherlands Institute of Engineers, The Hague, Sir Harold Hartley, chairman of the British National Committee, was elected by the
Council as its chairman, in succession to the late $\mathbf{M r}$. D. N. Dunlop, who died on May 30. The choice of Sir Harold is peculiarly appropriate, since as a vice-president of the London Midland and Scottish Railway Company, and director of research of that great transport system, he is in close touch with industrial problems, while as chairman of the Fuel Research Board and a research fellow of Balliol College, Oxford, he is also conversant with the more academic aspects of scientific progress. The Conference owes to Mr. Dunlop, its founder, a happy combination of the practical with the ideal. Under Sir Harold Hartley's guidance it should continue to progress and to play an increasingly influential rôle throughout the world.

\section{Dovedale}

Mr. Robert McDougall, of Manchester, has presented to the National Trust further sections of Dovedale. The dale lies partly in Derbyshire and partly in Staffordshire, and it was recently announced in Parliament that steps were being taken by the local authorities concerned for the planning of the whole area. This announcement was warmly welcomed by the National Trust. Now Mr. McDougall has added to his previous gifts 52 acres in Biggin Dale which joins Wolfscote Dale-as the upper part of the Dove valley is called $\rightarrow$ on the Derbyshire side some way above the land recently given by Imperial Chemical Industries, Ltd. Biggin Dale is a dry limestone gorge of great beauty. The new property, on its north-western side, consists of steep grass slopes with picturesque screes and some timber and haw. thorn bushes, and from it there are arresting views down the Dove valley. There are also fine views across to the Staffordshire side of the Dove valley where the Peasland Rocks stand out boldly. Above the property is Wolfscote Hill (1,272 ft.) which, with its long ridge, is a grèat landmark in the neighbourhood.

\section{Italian Council of Research}

THE recent activities of the Italian National Council of Research, which is directed by the Marchese Marconi, are described in an official publication dealing with investigations which the Council has handed over to the universities, higher teaching centres and experimental stations in Italy. During the years 1933 and 1934, researches were carried out in the problems of nutrition in the laboratories and institutes of physiology and biochemistry at Naples, Padua, Genoa and Rome, as well as investigations on the etiology, epidemiology and prophylaxis of typhoid fever in the institutes of hygiene at Bologna and Genoa.

\section{Toxicity of Industrial Solvents}

AT the request of the Home Office, the Medical Research Council has undertaken to promote investigation into the question whether various volatile substances might injure the health of workers using them under industrial conditions. The Council has appointed the following special committee to assist and advise in this matter : Sir Joseph Barcroft 